\title{
Non-Measurable Tumor Identification
}

National Cancer Institute

\section{Source}

National Cancer Institute. Non-Measurable Tumor Identification. NCI Thesaurus. Code C103423.

The identification of a tumor that is incapable of being measured at baseline. 